\title{
Independence of progesterone blockade of the luteinizing hormone surge in ewes from opioid activity at naloxone-sensitive receptors
}

\author{
W. D. Currie*, J. Ravindra, D. L. Kingsbury and N. C. Rawlings $\dagger$ \\ Veterinary Physiological Sciences, University of Saskatchewan, Saskatoon, \\ Saskatchewan S7N OWO, Canada
}

\begin{abstract}
Summary. Fifteen ovariectomized ewes were treated with implants (s.c.) creating circulating luteal progesterone concentrations of $1.6 \pm 0.1 \mathrm{ng} \mathrm{ml}^{-1}$ serum. Ten days later, progesterone implants were removed from five ewes which were then infused with saline for $64 \mathrm{~h}\left(0 \cdot 154 \mathrm{~mol} \mathrm{NaCl} 1^{-1}, 20 \mathrm{ml} \mathrm{h}^{-1}\right.$, i.v. $)$. Ewes with progesterone implants remaining were infused with saline $(n=5)$ or naloxone $\left(0.5 \mathrm{mg} \mathrm{kg}^{-1} \mathrm{~h}^{-1}, n=5\right)$ in saline for $64 \mathrm{~h}$. At $36 \mathrm{~h}$ of infusion, all ewes were injected with oestradiol $(20 \mu \mathrm{g}$ in $1 \mathrm{ml}$ groundnut oil, i.m.). During the first $36 \mathrm{~h}$ of infusion, serum luteinizing hormone (LH) concentrations were similar in ewes infused with saline after progesterone withdrawal and ewes infused with naloxone, but with progesterone implants remaining $\left(1.23 \pm 0.11\right.$ and $1.28 \pm 0.23 \mathrm{ng} \mathrm{ml}^{-1}$ serum, respectively, mean $\left.\pm \mathrm{SEM}, P>0.05\right)$. These values exceeded circulating LH concentrations during the first $36 \mathrm{~h}$ of saline infusion of ewes with progesterone implants remaining $\left(0.59 \pm 0.09 \mathrm{ng} \mathrm{ml}^{-1}\right.$ serum, $P<0.05)$. The data suggested that progesterone suppression of tonic LH secretion, before oestradiol injection, was completely antagonized by naloxone. After oestradiol injection, circulating $\mathrm{LH}$ concentrations decreased for about $10 \mathrm{~h}$ in ewes of all groups. A surge in circulating $\mathrm{LH}$ concentrations peaked $24 \mathrm{~h}$ after oestradiol injection in ewes infused with saline after progesterone withdrawal $\left(8 \cdot 16 \pm 3 \cdot 18 \mathrm{ng} \mathrm{LH} \mathrm{ml}^{-1}\right.$ serum $)$. At the same time, circulating LH concentrations in ewes infused with saline or naloxone, but with progesterone implants remaining, were similar to concentrations observed before injection $\left(0.91 \pm 0.27\right.$ and $1.35 \pm 0.28 \mathrm{ng} \mathrm{LH} \mathrm{ml}^{-1}$ serum, respectively). The results suggested that naloxone antagonism of opioid-dependent progesterone suppression of $\mathrm{LH}$ secretion was not equivalent to progesterone withdrawal. It was concluded that progesterone blockade of oestradiol positive feedback on LH secretion in ewes does not depend upon endogenous opioid peptide activity at naloxone-sensitive receptors.
\end{abstract}

Keywords: opioids; luteinizing hormone surge; oestradiol; progesterone; naloxone; sheep

\section{Introduction}

Acute oestradiol administration has a biphasic effect on luteinizing hormone (LH) secretion in ovariectomized ewes (Scaramuzzi et al., 1971; Coppings \& Malven, 1976). Reduced LH secretion due to initial oestradiol negative feedback is followed $12-48 \mathrm{~h}$ later by a surge of $\mathrm{LH}$ secretion exceeding pretreatment concentrations, oestradiol positive feedback (Karsch et al., 1980; Goodman et al., 1981a,b). The surge of LH secretion following oestradiol administration to

\footnotetext{
*Present address: Obstetrics and Gynecology, Grace Hospital, University of British Columbia, Vancouver, British Columbia V6H 3V5, Canada.

$\dagger$ For reprints.
} 
ovariectomized ewes is smaller in magnitude (Scaramuzzi et al., 1971; Schillo et al., 1985), but similar in time course, to the preovulatory gonadotrophin surge (Rawlings et al., 1984). A similar increase in LH secretion follows progesterone withdrawal in ovariectomized ewes treated with progesterone and low, constant concentrations of oestradiol for 10 days (Rawlings et al., 1984). However, oestradiol fails to exert positive feedback on $\mathrm{LH}$ secretion in ewes with circulating luteal progesterone concentrations (Jeffcoate et al., 1984; Martin, 1984).

Most, perhaps all (Currie et al., 1991 a), progesterone suppression of tonic LH secretion in ewes depends upon opioid activity at naloxone-sensitive opioid receptors (Malven et al., 1984; Brooks et al., 1986a, b; Currie \& Rawlings, 1987, 1989; Trout \& Malven, 1987; Yang et al., 1988). Reduced opioid activity may be one mechanism allowing increased LH secretion during the follicular phase and gonadotrophin surge (Knight et al., 1990; Currie et al., 1991b).

This study tested the hypothesis that progesterone blockade of oestradiol positive feedback on LH secretion in ewes depends upon opioid activity at naloxone-sensitive receptors. The hypothesis was tested by acute oestradiol administration during naloxone infusion of progesterone-implanted ovariectomized ewes. The trial was performed in ovariectomized, rather than intact, ewes, as naloxone does not antagonize the synergistic suppression of $\mathrm{LH}$ secretion by progesterone and oestradiol (Currie et al., 1991a). Circulating progesterone and oestradiol can be detected in ewes during the luteal phase (Currie \& Rawlings, 1987, 1989).

\section{Materials and Methods}

\section{Animals}

Fifteen Columbia ewes were housed in a drylot and fed pelleted lucerne $(1.2 \mathrm{~kg}$ per ewe per day), with hay, mineralized salt and water provided ad libitum. The ewes were housed with marker-harnessed vasectomized rams and had regular oestrous cycles. The ewes were ovariectomized under halothane (Somnathane: Hoechst Inc., Montreal, Quebec, Canada) anaesthesia 2 weeks before the experiment.

\section{Experimental treatments}

The experiment was performed during the breeding season (early December). The ewes were divided into three groups of five and housed indoors in three pens $(2.5 \times 2.5 \mathrm{~m})$. The trials were performed indoors, at $13^{\circ} \mathrm{C}$, with lighting conditions simulating natural daylength. Fluorescent $(890$ lux $)$ and incandescent red $(<50$ lux $)$ light were used during normal hours of daylight and darkness, respectively. All of the ewes were treated with Silastic implants (s.c.) to create luteal progesterone concentrations (4-pregnene-3,20-dione: Sigma, St Louis, MO, USA) (Rawlings et al., 1984). One day before infusions, vinyl catheters (i.d. $1.00 \mathrm{~mm}$, o.d. $1.50 \mathrm{~mm}$, SV-70; Dural Plastics and Engineering, Dural, NSW) were inserted into both jugular veins of each ewe. During infusions, ewes were housed side by side in $1.0 \times 1.5 \mathrm{~m}$ carts, with pelleted lucerne, hay and water available. The ewes were randomly assigned to three groups.

\section{Group 1}

Ten days after insertion of progesterone implants, five ewes were infused with saline $\left(0 \cdot 154 \mathrm{~mol} \mathrm{NaCl} \mathrm{I}^{-1}, 20 \mathrm{ml}\right.$ $\mathrm{h}^{-1}$ ) for $64 \mathrm{~h}$. Infusions were via a multi-channel peristaltic pump (Cassette Pump, Manostat, New York, NY, USA) connected to the left jugular catheter with silicone rubber tubing (i.d. $2.38 \mathrm{~mm}$, o.d. $3.97 \mathrm{~mm}$; Manosil, Manostat). Ewes were injected with oestradiol ( $20 \mu \mathrm{g}$ in $1 \mathrm{ml}$ groundnut oil, i.m., $\beta$-oestradiol, Sigma, St Louis, MO, USA) at $36 \mathrm{~h}$ of infusion.

\section{Group 2}

Progesterone implants were removed 10 days after insertion. Five ewes were then infused with saline for $64 \mathrm{~h}$. Ewes were injected with oestradiol $(20 \mu \mathrm{g}, \mathrm{i} . \mathrm{m}$.) at $36 \mathrm{~h}$ of infusion.

\section{Group 3}

Ten days after insertion of progesterone implants, five ewes were infused with naloxone hydrochloride $(0.5 \mathrm{mg}$ $\mathrm{kg}^{-1} \mathrm{~h}^{-1}$; DuPont Pharmaceuticals, Garden City, NY, USA) in saline for $64 \mathrm{~h}$. Ewes were injected with oestradiol $(20 \mu \mathrm{g}$, i.m.) at $36 \mathrm{~h}$ of infusion. 


\section{Samples}

Blood samples were collected by venepuncture, once a day for 10 days prior to infusion. Blood samples were collected via the right jugular catheter, once an hour throughout infusions. Samples were allowed to clot for $12 \mathrm{~h}$ at $20^{\circ} \mathrm{C}$. Clots were removed and serum was centrifuged at $1500 \mathrm{~g}$ for $15 \mathrm{~min}$. Serum was separated from remaining red blood cells and stored at $-20^{\circ} \mathrm{C}$ until analysed.

\section{LH assay}

All serum samples collected during infusions were analysed for LH by radioimmunoassay (Rawlings et al., 1984). Serum LH concentrations are expressed in terms of NIAMDD oLH-24. Intra- and interassay coefficients of variation (CVs) for an ovine reference serum with a mean of $2.60 \mathrm{ng} \mathrm{LH} \mathrm{ml}^{-1}$ were $4.1 \%$ and $6.0 \%$, respectively, and $5.9 \%$ and $8.1 \%$, respectively, for a reference serum of $1.48 \mathrm{ng} \mathrm{LH} \mathrm{ml}^{-1}$. Sensitivity of the LH assay, expressed as the lowest standard different from zero by unpaired $t$-test, was $0.1 \mathrm{ng} \mathrm{ml}^{-1}$ serum $(P<0 \cdot 05)$.

\section{Steroid assays}

Daily serum samples collected before infusions were analysed for progesterone and oestradiol by radioimmunoassay (Rawlings et al., 1984; Jeffcoate et al., 1984). Intra- and interassay CVs, for ovine reference sera with means of 10 and $16 \mathrm{pg}$ oestradiol $\mathrm{ml}^{-1}$ were both $11 \%$ and $17 \%$, respectively. Sensitivity of the oestradiol assay was $1.0 \mathrm{pg} \mathrm{ml}^{-1}$ serum $(P<0.05)$. Intra- and interassay CVs, respectively, for an ovine reference serum with a mean of $1.0 \mathrm{ng}$ progesterone $\mathrm{ml}^{-1}$ were $9.9 \%$ and $19 \%$, respectively, and $8.5 \%$ and $15 \%$, respectively, for a reference serum of $2.2 \mathrm{ng}$ progesterone $\mathrm{ml}^{-1}$. Sensitivity of the progesterone assay was $0.1 \mathrm{ng} \mathrm{ml}^{-1}$ serum $(P<0.05)$.

\section{Statistical analysis}

Comparisons of circulating LH concentrations between groups were by one-way analysis of variance of (i) the mean of all hourly LH data from each ewe prior to oestradiol injection and (ii) the circulating LH concentration for each ewe $24 \mathrm{~h}$ after oestradiol injection. After a significant $F$-test, means were separated with Scheffe's test (GB-STAT 2.0, 1988, Dynamic Microsystems, Silver Springs, MD, USA).

\section{Results}

During the 10 days before infusion, ewes were treated in the same way. During this period, serum progesterone and oestradiol concentrations were $1.6 \pm 0.1 \mathrm{ng} \mathrm{ml} \mathrm{m}^{-1}$ and $3.2 \pm 0.2 \mathrm{pg} \mathrm{ml}^{-1}$, respectively. During the first $36 \mathrm{~h}$ of infusion, serum LH concentrations were similar in ewes infused with saline after progesterone withdrawal and in ewes infused with naloxone, but with progesterone implants remaining $\left(1.23 \pm 0.11\right.$ and $1.28 \pm 0.23 \mathrm{ng} \mathrm{LH} \mathrm{ml}^{-1}$ serum, Groups 2 and 3 , respectively, mean \pm SEM, $P>0.05$, Fig. 1). These values exceeded circulating $\mathrm{LH}$ concentrations during the first $36 \mathrm{~h}$ of saline infusion of ewes with progesterone implants remaining (Group 1, $0.59 \pm 0.09 \mathrm{ng} \mathrm{LH} \mathrm{ml}^{-1}$ serum, $P<0.05$ ). For approximately $10 \mathrm{~h}$ after oestradiol injection, mean circulating LH concentrations within each group were lower than those observed during the first $36 \mathrm{~h}$ of infusion. After this apparent decline, a surge in circulating LH concentrations, above pre-oestradiol injection concentrations $(P<0.05)$, was detected in ewes infused with saline following progesterone withdrawal (Group 2). Circulating LH concentrations in this group peaked $24 \mathrm{~h}$ after oestradiol injection $\left(8 \cdot 16 \pm 3 \cdot 18 \mathrm{ng} \mathrm{LH} \mathrm{ml}^{-1}\right.$ serum). At the same time, circulating LH concentrations were less in ewes infused with saline (Group 1) or naloxone (Group 3 ) but with progesterone implants remaining $\left(0.91 \pm 0.27\right.$ and $1.35 \pm 0.28 \mathrm{ng} \mathrm{ml}^{-1}$ serum, respectively, $P<0.05$ ).

\section{Discussion}

Oestradiol positive feedback is manifested as increased frequency of luteinizing-hormone-releasing hormone (LHRH) secretion from the hypothalamus (Schillo et al., 1985; Clarke et al., 1987) and 

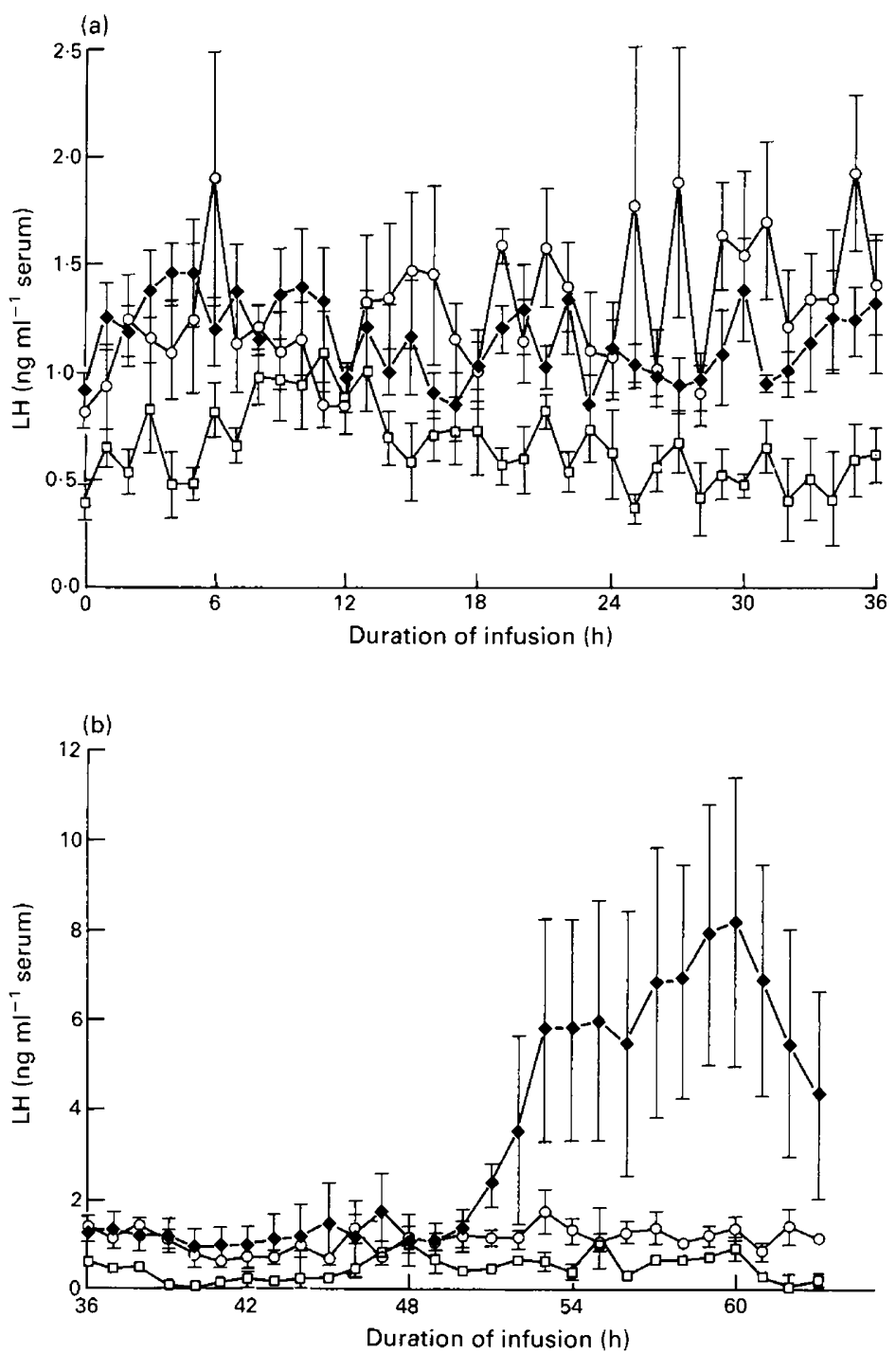

Fig. 1. Circulating luteinizing hormone concentrations (mean \pm SEM) in ovariectomized ewes ( $n=5$ per group) treated for 10 days with implants (s.c.) creating circulating luteal progesterone concentrations and injected with $20 \mu \mathrm{g}$ oestradiol (i.m.) at $36 \mathrm{~h}$ of infusion (i.v.). (a) data before, and (b) data after oestradiol injection. Group 1: ( $\square$ ) saline infusion for $64 \mathrm{~h}$, with progesterone implants remaining; group 2: $(\diamond)$ saline infusion for $64 \mathrm{~h}$ after progesterone withdrawal; group 3: $(O)$ naloxone infusion $\left(0.5 \mathrm{mg} \mathrm{kg}^{-1} \mathrm{~h}^{-1}\right)$ for $64 \mathrm{~h}$ with progesterone implants remaining.

increased pituitary responsiveness to LHRH (Coppings \& Malven, 1976). Oestradiol directly increases pituitary responsiveness to LHRH (Reeves et al., 1971; Jackson, 1975; Moss \& Nett, 1980), reflecting increased LHRH receptor numbers and gonadotrophin synthesis (Landefeld et al., 1985). Oestradiol fails to exert positive feedback on LH secretion in ewes with circulating luteal progesterone (Jeffcoate et al., 1984; Martin, 1984). Progesterone has been shown to suppress LHRH pulsatility (Karsch et al., 1987). However, physiological progesterone concentrations have little effect on pituitary responsiveness to LHRH (Goodman \& Karsch, 1980). This suggests that 
progesterone blockade of oestradiol positive feedback results from progesterone suppression of LHRH secretory frequency (Goodman \& Karsch, 1980).

Morphine suppresses LH secretory frequency in ovariectomized ewes, mimicking effects of progesterone replacement (Currie \& Rawlings, 1989; Currie et al., 1991a). Naloxone enhances LH secretory frequency in progesterone-treated ovariectomized ewes and intact ewes during the luteal phase mimicking effects of progesterone withdrawal (Currie \& Rawlings, 1987, 1989; Currie et al., 1991a). Simultaneous infusion of ovariectomized ewes with morphine and naloxone does not affect LH secretion. This suggests that effects of morphine and naloxone on LH secretion are mediated at a common specific receptor (Currie et al., 1991a).

Naloxone-reversible opioid suppression of LH secretion is reduced in ewes during the follicular phase (Brooks et al., 1986b; Currie et al., 1991b). This suggests that reduced opioid activity may be permissive to the preovulatory gonadotrophin surge (Currie et al., 1991b). Hourly morphine administration throughout the follicular phase and oestrus delayed by $17 \mathrm{~h}$, but failed to block, the gonadotrophin surge (Currie et al., 1991b). Morphine and naloxone failed to affect the oestradiolinduced LH surge in anoestrous ewes (Horton \& Clarke, 1988). However, acute administration of a potent enkephalin analogue, FK 33-824, to ewes during the follicular phase delayed ovulation by nearly 2 weeks (Brooks et al., 1986b). FK 33-824 reduced total LH secreted during an oestradiolstimulated gonadotrophin surge in anoestrous ewes, an effect partially reversed by naloxone (Knight et al., 1990). However, FK 33-824 failed to block or delay the oestradiol-induced LH surge in intact or ovariectomized ewes during anoestrus (Knight et al., 1990). Examination of opioid involvement in the gonadotrophin surge in ewes appears to be affected by season, recent ovarian steroid exposure and opiate analogue used.

In this study, tonic LH concentrations prior to oestradiol injection were similar $(P>0.05)$ in ewes infused with saline following progesterone withdrawal (Group 2) and ewes infused with naloxone, but with progesterone implants remaining (Group 3). These LH concentrations were greater $(P<0.05)$ than in ewes infused with saline, but with progesterone implants remaining (Group 1). This suggested that progesterone suppression of tonic LH secretion, before oestradiol injection, was antagonized by naloxone (Fig. 1). The results support the contention that a major portion of progesterone suppression of tonic LH secretion depends on opioid activity at naloxonesensitive receptors (Currie et al., 1991a).

After oestradiol injection at $36 \mathrm{~h}$ of infusion, $\mathrm{LH}$ suppression was observed in ewes of all groups (Fig. 1). A secondary positive response of $\mathrm{LH}$ secretion to oestradiol was observed in ewes from which progesterone was withdrawn (Group 2). Despite the antagonism of opioid-dependent progesterone suppression of tonic $\mathrm{LH}$ secretion by naloxone, oestradiol failed to exert positive feedback in ewes infused with saline or naloxone, but with progesterone remaining (Groups 1 and 3 ). This suggested that antagonism of opioid activity by naloxone was not equivalent to progesterone withdrawal. Opioid activity at naloxone-sensitive receptors may represent a component of progesterone blockade of oestradiol positive feedback, slowing LHRH pulse frequency. However, reduced opioid-dependent progesterone suppression of tonic $\mathrm{LH}$ secretion is not sufficient to permit oestradiol to induce a gonadotrophin surge. Progesterone blockade of oestradiol positive feedback may also involve nonopioid mechanisms or opioid activity at receptor types not sensitive to morphine (Currie et al., 199lb). Alternatively, the dose of naloxone used was insufficient to overcome opioid-dependent progesterone blockade of oestradiol positive feedback.

Multiple opioid receptor types have been implicated in suppression of LH secretion, with opioids from all major opioid precursors reported to suppress circulating LH levels in rats (Wuster et al., 1978) and men (Stubbs et al., 1978; Reid et al., 1981). Morphine and naloxone do not have identical affinities for all opioid receptor types. Morphine and naloxone bind with high affinity to $\mu_{1}$ - and $\mu_{2}$-receptors (Lord et al., 1977; Pasternak, 1986; Pasternak \& Wood, 1986; Kazmi \& Mishra, 1987). Enkephalins bind with high affinity to $\delta$ - and $\mu_{1}$-receptors (Lord et al., 1977; Pasternak \& Wood, 1986; Kazmi \& Mishra, 1987). Naloxone also binds with high affinity to $\delta$-receptors (Khatchaturian et al., 1985). Evidence obtained in this and previous studies (Horton \& 
Clarke, 1988; Currie et al., 1991b) suggests that reduced opioid activity at morphine or naloxonesensitive receptors is not critical to the gonadotrophin surge in ewes. A lengthy delay to ovulation followed FK 33-824 administration to ewes during the follicular phase (Brooks et al., 1986b). It is possible that progesterone blocks oestradiol positive feedback at an enkephalin-sensitive receptor that is not sensitive to naloxone. This may eliminate the involvement of opioid activity at $\mu_{1^{-}}, \mu_{2^{-}}$ and $\delta$-receptors in progesterone blockade of the gonadotrophin surge. Enkephalin blockade of the gonadotrophin surge may fail in anoestrus (Knight et al., 1990) owing to an absence of recent ovarian progesterone exposure.

Technical assistance was provided by S. Cook. Care and housing of ewes was provided by M. Buckley and the Animal Care Unit staff, Western College of Veterinary Medicine. LH for iodination was provided by L. E. Reichert, Jr. Standards for the LH assay were provided by NIAMDD. The study was funded by NSERC.

\section{References}

Brooks, A.N., Lamming, G.E. \& Haynes, N.B. (1986a) Endogenous opioid peptides and the control of gonadotropin secretion. Research in Veterinary Science 41, 285-299.

Brooks, A.N., Lamming, G.E., Lees, P.D. \& Haynes, N.B. (1986b) Opioid modulation of LH secretion in the ewe. Journal of Reproduction and Fertility 76, $693-708$.

Clarke, I.J., Thomas, G.B., Yao, B. \& Cummins, J.T. (1987) GnRH secretion throughout the ovine estrous cycle. Neuroendocrinology 46, 82-88.

Coppings, R.J. \& Malven, P.V. (1976) Biphasic effect of estradiol on mechanisms regulating $\mathrm{LH}$ release in ovariectomized sheep. Neuroendocrinology 21, 146-156.

Currie, W.D., Cook, S.J. \& Rawlings, N.C. (1991a) LH secretion in ovariectomized ewes: effects of morphine and ovarian steroid interactions with naloxone during the breeding season and anestrum. Canadian Journal of Animal Science 71, 333-342.

Currie, W.D., Joseph, I.B.J.K. \& Rawlings, N.C. (1991b) Morphine, naloxone and the gonadotrophin surge in ewes. Journal of Reproduction and Fertility 92, 407-414.

Currie, W.D. \& Rawlings, N.C. (1987) Naloxone enhances LH but not FSH during various phases of the estrous cycle in the ewe. Life Sciences 41, $1207-1214$

Currie, W.D. \& Rawlings, N.C. (1989) Prolonged infusion of morphine and naloxone in the ewe: fluctuation in responsiveness of $\mathrm{LH}$ and lack of responsiveness of FSH. Journal of Reproduction and Fertility 86, $359-366$.

Goodman, R.L., Bittman, E.L., Foster, D.L. \& Karsch, F.J. (1981a) The endocrine basis of the synergistic suppression of luteinizing hormone by estradiol and progesterone. Endocrinology 109, 1414-1417.

Goodman, R.L. \& Karsch, F.J. (1980) Pulsatile secretion of luteinizing hormone: differential suppression by ovarian steroids. Endocrinology 107, 1286-1290.

Goodman, R.L., Legan, S.J., Ryan, K.D., Foster, D.L. \& Karsch, F.J. (1981b) Importance of variations in behavioral and feedback actions of oestradiol to the control of seasonal breeding in the ewe. Journal of Endocrinology 89, 229-240.
Horton, R.J.E. \& Clarke, I.J. (1988) Lack of an effect of morphine or naloxone on the oestrogen-induced LH surge in anoestrous ewes. Journal of Endocrinology 119, 89-93.

Howard, A.D., Sarne, Y., Gioannini, T.L., Hiller, J.M. \& Simon, E.J. (1986) Identification of distinct binding site subunits of $\mu$ and $\delta$ opioid receptors. Biochemistry 25, 357-360.

Jackson, G.L. (1975) Blockage of estrogen-induced release of luteinizing hormone by reserpine and potentiation of synthetic gonadotropin-releasing hormone-induced release of luteinizing hormone by estrogen in the ovariectomized ewe. Endocrinology 97, 1300-1307.

Jeffcoate, I.A., Rawlings, N.C. \& Rieger, D.L. (1984) Progesterone and the surge release of gonadotropins in the ewe. Domestic Animal Endocrinology 1,309-317.

Karsch, F.J., Cummins, J.T., Thomas, G.B. \& Clarke, I.J. (1987) Steroid feedback inhibition of pulsatile secretion of gonadotropin-releasing hormone in the ewe. Biology of Reproduction 36, 1207-1218.

Karsch, F.J., Legan, S.J., Ryan, K.D. \& Foster, D.L. (1980) Importance of estradiol and progesterone in regulating $\mathbf{L H}$ secretion and estrous behavior during the sheep estrous cycle. Biology of Reproduction 23, $404-413$.

Kazmi, S.M.I. \& Mishra, R.K. (1987) Comparative pharmacological properties and functional coupling of $\mu$ and $\delta$ opioid receptor sites in human neuroblastoma SH-SY5Y cells. Molecular Pharmacology 32, 109-118.

Khatchaturian, H., Allesi, N.E., Lewis, M.E., Munfakh, N., Fitzsimmons, M.D. \& Watson, S.J. (1985) Development of hypothalamic opioid neurons: A combined immunocytochemical and $\left[{ }^{3} \mathrm{H}\right]$-thymidine autoradiographic study. Neuropeptides 5, 477-480.

Kmight, P.G., Stansfield, S.C. \& Cunningham, F.J. (1990) Attenuation by an opioid agonist of the oestradiolinduced LH surge in anoestrous ewes and its reversal by naloxone. Domestic Animal Endocrinology 7, $165-172$.

Landefeld, T., Kaynard, A. \& Kepa, J. (1985) Pituitary alpha-subunit messenger ribonucleic acid remains elevated during the latter stages of the preovula- 
tory luteinizing hormone surge. Endocrinology 117 , $934-938$

Lord, J.A.H., Waterfeld, A.A., Hughes, J. \& Kosterlitz, H.W. (1977) Endogenous opioid peptides: multiple agonist and receptors. Nature 267, 495-499.

Malven, P.V., Bossut, D.F.B. \& Diekman, M.A. (1984) Effects of naloxone and electroacupuncture treatment on plasma concentrations of LH in sheep. Journal of Endocrinology 101, 75-80.

Martin, G.B. (1984) Factors affecting the secretion of luteinizing hormone in the ewe. Biological Reviews 59, $1-87$

Moss, G.E. \& Nett, T.M. (1980) GnRH interaction with anterior pituitary. IV. Effect of estradiol-17 3 on GnRH mediated release of LH from ovine pituitary cells obtained during the breeding season, anestrous season and period of transition into or out of the breeding season. Biology of Reproduction 23, 398-403.

Pasternak, G.W. (1986) Multiple mu opiate receptors: biochemical and pharmacological evidence for multiplicity. Biochemical Pharmacology 35, 361.

Pasternak, G.W. \& Wood, P.J. (1986) Multiple mu opiate receptors. Life Sciences 38, 1889-1898.

Rawlings, N.C., Jeffcoate, I.A. \& Rieger, D.L. (1984) The influence of estradiol-17 $\beta$ and progesterone on peripheral serum concentrations of luteinizing hormone and follicle stimulating hormone in the ovariectomized ewe. Theriogenology 22, $473-488$.

Reeves, J.J., Arimura, A. \& Schally, A.V. (1971) Pituitary responsiveness to purified luteinizing hormonereleasing hormone ( $\mathrm{LH}-\mathrm{RH}$ ) at various stages of the estrous cycle in sheep. Journal of Animal Science 32, 123 131.

Reid, R.L., Hoff, J.D., Yen, S.S.C. \& Li, C.H. (1981) Effects of exogenous $\beta_{h}$-endorphin on pituitary hormone secretion and its appearance rate in normal human subjects. Journal of Clinical Endocrinology and Metabolism 52, 1179-1184.

Scaramuzzi, R.J., Tilson, S.A., Thorneycroft, I.F. \& Caldwell, B.V. (197I) Action of exogenous progesterone and estrogen on behavioral estrus and luteinizing hormone in the ovariectomized ewe. Endocrinology 88, $1184-1189$.

Schillo, K.K., Leshin, L.S., Kuehl, D. \& Jackson, G.L. (1985) Simultaneous measurement of luteinizinghormone-releasing hormone and luteinizing hormone during estradiol-induced luteinizing hormone surges in the ovariectomized ewes. Biology of Reproduction 33, $644-652$.

Stubbs, W.A., Delitala, G., Jones, A., Edwards, C.R.W. Jeffcoate, W.J., Ratter, S.J., Besser, G.M., Bloom, S.R. \& Alberti, K.G.M.M. (1978) Hormonal and metabolic responses to an enkephalin analogue in normal man. Lancet ii, 1225-1227.

Trout, W.E. \& Malven, P.V. (1987) Effects of exogenous estradiol-17 $\beta$ and progesterone on naloxonereversible inhibition of the release of luteinizing hormone in ewes. Journal of Animal Science 65, 1602-1609.

Wuster, M., Schulz, R. \& Herz, A. (1978) Specificity of opioids towards the mu, delta, and epsilon-opiate receptors. Neuroscience Letters 15, $193-198$.

Yang, K., Haynes, N.B., Lamming, G.E. \& Brooks, A.N. (1988) Ovarian steroid hormone involvement in endogenous opioid modulation of LH secretion in mature ewes during the breeding and non-breeding seasons. Journal of Reproduction and Fertility 83, 129-139.

Received 25 February 1991 